\title{
The State and the Imams: Summary of a Government Report on Training Programmes for Imams in Sweden ${ }^{1}$
}

\author{
Göran Larsson
}

\begin{abstract}
The aim of this article is to show how the issue of imam training programmes was analysed and discussed in the official Swedish report Staten och imamerna. Religion, integration, autonomi (The State and the imams: religion, integration, autonomy) (SOU 2009:52), issued by the Swedish Ministry of Education in 2009. The Swedish report is here described with reference to contemporary debates and discussions about integration, security and equal civil rights in Europe. The enquiry came to the conclusion that the Swedish state should not support a specific training programme for imams. The Swedish state should be confessionally neutral, and to start a specific training for imams at university level and on state initiative would conflict with confessional neutrality; in addition, to single out Muslims would signal that Muslims are considered to be a problem group more in need of training than other religious (especially other migrant religious) groups.
\end{abstract}

After the 9/11 atrocities in New York and Washington, the bombs in the Attocha station in Madrid (11 March 2004), the murder of Theo van Gogh in Amsterdam (2 November 2004), and the attacks on the London transportation systems (7 July 2005) a growing number of governments in Western Europe have become interested in the training of

\footnotetext{
${ }^{1}$ Unless otherwise indicated, all information and data in this article are taken from Staten och imamerna. Religion, integration, autonomi, SOU 2009:52). The whole report can be downloaded from http://www.sweden.gov.se/sb/d/11358/a/127317.
} 
imams (for an overview of this question, see, Drees \& van Koningsveld 2008; Larsson 2009; Schepelern Johansen 2005). The overarching questions could be formulated in the following way: 'Do imams contribute to integration, peace and harmony, or do they foster division and hatred of non-Muslims in Europe?' But even though the training of imams has recently been connected with the question of security and the growing fear of terrorism in Europe, significantly this issue is also closely related to the questions of integration and equal rights for all citizens, no matter what their ethnic, social and religious backgrounds.

Before I discuss the Swedish enquiry into imams, it is worth remembering that imams have actually received training in Europe since long before the rise of modern terrorism in the name of Islam. Imam training institutions have, for example, existed in BosniaHerzegovina since the sixteenth century, they also received training during the Second World War in Nazi Germany, and a more recent example is the growing number of Pakistani and Bangladeshi Muslim communities that have founded training institutions for imams in the UK since the 1970s (see Drees \& van Koningsveld 2008; Gilliat-Ray 2006; Larsson 2009; Schepelern Johansen 2005). Despite the existence of these institutions of higher Muslim learning, it is clear that most Western governments were uninterested in the education of imams prior to the rise of terrorism in the West.

With the terror attacks on European soil, mentioned above, it became painfully clear to a mounting number of Europeans that the great majority of the terrorists involved had actually been born and raised in the West. The crucial question was how to combat radicalization and extremism in Europe. Public discussion became heated, and populist parties across the continent argued that migration, Islam and Muslims were the root problem and that Islam was incompatible with so-called Western norms and values. Muslims were often portrayed as Trojan horses disloyal to their host countries. Other voices argued that the problem was segregation, racism and frustration among migrant groups (see Gilliat-Ray 2006; Haddad \& Balz 2008). It was also common to analyse terrorist acts as a response to Western policies in the Muslim world (especially in Iraq, but also in Palestine, Chechnia and Kashmir). The provocation of and hatred for Islam 
and Muslims was also allegedly illustrated by the Muhammad cartoon crisis and the Danish government's unwillingness to listen to the Muslims. Without going into any detail, it is evident that the post-9/11 public discussion has been and still is very emotional and heated when it comes to the question of Islam, Muslims, multiculturalism, migration and European identities (see, for example, Amnå 2010; Haddad \& Balz 2008; Klausen 2004; Larsson 2009; Nielsen 2005).

One response to the political turmoil that followed the incidents and discussions described above was the attempt to set up specific training programmes for imams in order to make them (i.e. the imams) more 'efficient' in combating violent and extreme interpretations of Islam that would support or create so-called parallel societies. On the one hand, this support for Islamic education by Western governments can be interpreted as a right given to Muslims. As citizens they should have equal opportunities to uphold their own traditions and values as long as these do not conflict with Western legal traditions (Amnå 2010; Larsson 2010). However, it is also evident that education can function as an instrument for control and influence. To put it in the words of Jonathan Birt (2006), the debate was often related to the question of 'good' and 'bad' imams. A 'good' imam was generally interpreted as an imam who was loyal to Western governments and was willing to function as a tool for integration and harmony. The 'bad' imam was primarily one who failed to pay any attention to these questions and whose interest was mainly focused on Islamic theology. In the worst case his primary focus is on Islamic interpretations that uphold values that hinder integration and that are contrary to Western legal systems (Birt 2006).

Against this backdrop, a number of governmental and non-governmental initiatives have recently been set up to meet the demand for the education of imams in Europe. These programmes have all been formulated and adjusted to fit local regulations and to meet the relationships between the state and religious bodies in the countries concerned. Without any attempt to make an empirical study of the educational systems set up for imam training programmes in Europe, it is clear that most initiatives and debates have taken place in the Netherlands and Germany. The existing programmes in these 
countries have been analysed, supported and criticized in both public media and academic publications. But the aim of my paper is not to outline the European discussion of imam training programmes or to present local differences in general (for such a discussion and analysis, see Drees \& van Koningsveld 2008; Larsson 2009; Schepelern Johansen 2005)). The specific contents of these initiatives and their historical roots in classical Islamic higher learning are not the topics of this paper (on this discussion, see, for example, Hefner \& Zaman 2007). My aim is rather to show how the issue of imam training programmes was analysed and discussed in the official report Staten och imamerna. Religion, integration, autonomi (The State and the Imams: Religion, Integration, Autonomy), issued by the Ministry of Education in Sweden in 2009 (SOU 2009). Contrary to the above initiatives, the Swedish government has so far rejected the idea of specific training programmes for imams at Swedish universities. It is important to stress that the government is not opposed to Muslims starting their own training institutions (confessional or non-confessional) or taking part in relevant courses at universities and other academic institutions.

Before I present the arguments employed in the governmental report, the reader should know that I took part in the enquiry as an expert on Islam and Muslims in Sweden. The official report was well received by both academics and governmental and nongovernmental organizations given the opportunity to comment on it (for more details, see Larsson 2010). That said, it should also be emphasized that some individual Muslim leaders, as well as the then Minister of Education in Sweden, Lars Leijonborg, were not happy with the report's conclusions (see Larsson 2010). Some Muslims, for example, were disappointed that the Swedish state was unwilling to pay for a training programme for imams that would cover the students' costs and salaries for the imams. However, this criticism was not shared by all imams, and the majority seemed to be content with the final conclusions and the work of the enquiry. The Minister of Education expressed his belief that imams were still in need of a special training programme to prepare them to work in Swedish society and uphold so-called Swedish values (see Larsson 2010), but he too accepted the conclusions of the enquiry. 


\section{The Background}

Besides the obvious fact that the Swedish government was aware of the ongoing European discussions on imam training programmes, the incentive to commission an official enquiry came from the Ministry of Education and Culture, which had been approached by Muslim groups asking whether it would be possible to support a specific training programme that would make it easier for imams to work more efficiently in Sweden (SOU 2009:15). The Muslim groups that had been in contact with government bodies had, among many other things, pointed out that Muslim religious leaders (i.e. imams) can both support and hinder integration. If they are not well educated, they warned, imams have the potential to become a problem for society, but if they are part of the social system, then they have the great potential to foster peaceful coexistence and harmony and to facilitate integration. In order to consider both the possibility and the need for imams in Sweden to be educated, the Minister of Education, Lars Leijonborg, commissioned an official report on this question. The enquiry, conducted between 22 May 2008 and 1 June 2009, was to focus on the following:

- To map and analyse the need for the training of imams in Sweden that had been pointed out by Muslim groups and organizations,

- To describe and analyse the needs that imams ask for when it comes to language training, theology and knowledge about Swedish society.

- To investigate whether the educational programmes that exist in Sweden can meet the needs of the imams and whether they could be adjusted to meet this demand.

- To describe how other European states have handled the so-called imam question. ${ }^{1}$

The enquiry was led and supervised by Professor Erik Amnå, Professor of Political Science at Örebro University, Sweden.

\footnotetext{
${ }^{1}$ See Kommittédirektiv: Utbildning för imamer, Dr. 2008:66. Retrieved from http://www.ud.se/sb/d/108/a/105784. Also published in SOU 2009: 111-15.
} 


\section{The Investigation}

In order to answer the questions raised above, it was necessary to collect information on the situation of imams in Sweden. Three methods were used to collect the material for the report.

As an initial procedure, it was necessary to collect quantitative data on the number of individuals who were working as imams in Sweden, their training background, whether they were interested in a possible training programme and what this programme should include. In order to contact as many imams as possible, the Swedish government body Nämnden för statligt stöd till trossamfund (Commission for Government Support to Faith Communities, SST) was contacted to help the enquiry contact Islamic organizations. When the report was written, SST was able to give contact information concerning 181 Islamic organizations and mosques in Sweden that had received state grants via SST. These organizations were contacted, and the imam of each was asked to fill out information about his training background, the number of hours he worked as an imam during a regular week, and whether he was interested in a training programme for imams being set up in Sweden. Of the 121 responses that were returned, it was clear that most individuals working as imams in Sweden have a long training background from a number of different countries, that a large majority only worked as imams in their free time and that they also had other jobs to support themselves and their families. Most of the respondents were interested in and positive about a Swedish imam training programme, but they were mainly interested in improving their knowledge of the Swedish language, the history of the country and family counselling techniques; most were not interested in an academic, non-confessional study of religion in general or of Islam in particular (SOU 2009: 38-48, 117-21).

As a second method, meetings were set up with both Muslim and non-Muslim interest groups in society in towns and cities including Uppsala, Stockholm, Örebro, Göteborg and Malmö. Meetings with representatives of municipalities, interest groups (for 
example, the Church of Sweden), educational institutions (for example, universities), the Muslim vocational training institution Ibn Rushd ${ }^{1}$ and government bodies were also organized in 2009. A research meeting was also conducted in Stockholm with experts from Germany, the Netherlands, Denmark and Norway. The speakers from municipalities and universities were invited to give their opinions about imam training programmes in Europe (SOU 2009:48-53, 123-4). It was very important to organize different meetings with various representatives, and the enquiry had to be transparent and open for dialogue and invite the participation of as many groups and individuals as possible.

As a third method, we (i.e. Erik Amnå and the two secretaries to the enquiry) tried to meet as many imams as possible, and approximately twenty meetings with representatives of Sunni, Shia and Ahmadiyya Muslims were organized (SOU 2009:123-4). These meetings were informal and the aim was to collect information and to discuss with imams the possible pros and cons of the setting up of a Swedish imamtraining programme. At the end of the work of the enquiry a large meeting with imams from the whole country was organized in Stockholm in order to inform them about the work and to give them the opportunity to discuss and comment on the final conclusions.

\section{Conclusions}

On the basis of the information and data collected and the meetings with imams and other counterparts mentioned above, the enquiry came to the following conclusions (see SOU 2009:81-109). Even though it could be important to support imams in their work for the integration and participation of Muslims in society, it was felt to be against the principles of the state to support any one specific religious group. The Swedish state should be confessionally neutral, and to start a specific training for imams could also be difficult since it would send a signal that Muslims are considered a problem group more in need of training than other religious (especially other migrant religious) groups. To

\footnotetext{
${ }^{1}$ For this non-governmental institution see Ibn Rushd - ett nytt studieförbund. En utvärdering av Ibn Rushds väg till statsbidragsberättigat studieförbund. Folkbildningsrådet utvärderar No. 12008.
} 
set up an imam training programme could even fuel Islamophobia and hatred for Muslims in Swedish society. Furthermore, it is also wrong for the state to stress the importance of imams. The state should rather emphasize that different government bodies and municipalities are free to start training programmes on their own if they think that imams are in need of better training to be able to participate and work in institutions such as, for example, hospitals, prisons and other social services.

It was also evident that the imams and other Muslim representatives who participated in the enquiry were not interested in receiving training in Islamic theology or religious studies that were taught by non-Muslim academics (i.e. lecturers in religious studies at Swedish universities) and that most of them were reluctant to borrow money for this kind of training. The imams in the enquiry were also unable to present any alternative to a training programme, and it would be impossible for the Swedish state to start several programmes that, for example, paid attention to different Islamic law schools.

It was also pointed out that the existing European initiatives in Germany and the Netherlands had not been successful in solving internal tensions within and between different Muslim groups. In general the enquiry found that most European initiatives had suffered from low support from the Muslim community and that they had not been able to solve the problems of integration and participation in society faced by most imams in Europe. It was also argued that the existing European imam training programmes had been unable to reach out to those imams who were in greatest need of training. Imams holding radical, violent or anti-Western opinions were unlikely to attend these programmes.

In conclusion it was stressed rather that the state should improve and support the existing training systems that were available at universities and other academic institutions to help imams acquire a better knowledge of the Swedish language and of Swedish society in general. No imam training programme was going to solve the problems of the Muslim community, and in the worst case scenario it could even be used as an excuse for Islamophobia and discrimination against Muslims. The Swedish 
state should rather strive for equality and confessional neutrality and support freedom of religion. Professor Erik Amnå, who was responsible for consultation with imams in Sweden as part of the enquiry discussed in this article, points to the future when he stresses that Swedish bureaucrats have to learn more about democracy and multiculturalism. He writes:

To begin with, the more or less hidden tradition of a partial religious embedding of public institutions has to be publicly scrutinised and replaced by the principle of the fair, equal and confessional neutral treatment of all citizens. Since minority and migration groups in the Swedish context are substantially identical, welfare policies must be used to wipe out the differences that cause particular harm to them, primarily due to their lack of socioeconomic resources. Furthermore, to strengthen diversity and pluralism within the common constitutional framework of values, civil society organisations as well as government institutions have to realise and value the fact that their cooperative interdependence necessitates mutual independence. Tendencies towards subordination and colonisation have to be countered. Consequently, educational institutions must be rewarded with continuous support by bringing young and old citizens together jointly to reflect, review and reshape those common values that are necessary to keep societies together, as well as those values that are necessary to keep societies plural with autonomy in all other respects. (Amnå 2010:21).

However, when the enquiry's report was presented on 1 June 2009, the then Minister of Education, Lars Leijonborg, said that he 'respected' the conclusions that were presented in the report, but he still believed that imams in Sweden were in need of training (Larsson 2010). Nonetheless the government bodies and other interest groups that were given an opportunity to respond to the enquiry were in general positive (for further references, see Larsson 2010), though at the time of writing this summary, discussion about a Swedish imam training programme is non-existent. Some Muslim groups have expressed the ambition to start a kind of training programme for imams, but this attempt 
is still very preliminary, and there is no massive demand for a training programme among Swedish Muslims at the moment.

In analysing the work of the Swedish imam enquiry, it is evident that the discussion about the possibility of starting an imam training programme in Sweden was also greatly coloured by the fact that the former state Church of Sweden has established a new relationship with the Swedish state. Since 2000 Sweden has no longer had a state church, and the government is therefore more eager to stress that all religious institutions and bodies should be treated equally. To start an imam training programme with confessional components would have been a clear break with this development, and the enquiry therefore stressed that the state should remain neutral when it comes to confessional matters and religious belief. From this point of view the final results and recommendations of the enquiry clearly illustrate how the Swedish government is striving to make a clear separation between church (religion) and state. Departments of religious studies at Swedish universities also received criticism from the Swedish national agency for higher education in 2010/2011 for not making a clear distinction between confessional beliefs and the academic study of religion when it comes to courses in religious studies at Swedish universities. This is yet another illustration of the fact that the Swedish state is trying to maintain a strict separation between church and state. Accordingly the imam enquiry felt it would be a move in the wrong direction to make possible confessional Islamic religious education in the universities. Besides the fact that most imams would be unlikely to agree on any one imam training programme capable of uniting all branches of Muslims and that they were uninterested in religious training given by non-Muslims, it is evident that the enquiry was informed by the government's attempt to separate church (and religion generally) from the state.

\section{References}

Amnå, Erik, 2010: "Scandinavian Democracies Learning Diversity: From Socialisation Between Lutherans to Training of Imams”, in: Karin Sporre and Jan Mannberg 
(eds): Values, Religions and Education in Changing Societies, Springer, Dordrecht, pp. 9-22.

Birt, Jonathan, 2006: “Good Imam, Bad Imam: Civic Religion and National Integration in Britain post 9/11", in: The Muslim World, 96: 687-705.

Drees, Willem B., and Pieter Sjoerd van Koningsveld (eds.), 2008: The Study of Religion and the Training of Muslim Clergy in Europe, Leiden University Press, Leiden.

Gilliat-Ray, Sophie, 2006: "Educating the Ulama: Centres of Islamic Religious Training in Britain", in: Islam and Christian-Muslim Relations, 17: 55-76.

Haddad, Yvonne Yazbeck, and Michael J. Balz, 2008: “Taming the Imams: European Governments and Islamic Preachers since 9/11", in: Islam and ChristianMuslim Relations, 19, 2: 215-235.

Hefner, Robert W., and Muhammad Qasim Zaman (eds.), 2007: Schooling Islam: The Culture and Politics of Modern Muslim Education, Princeton University Press, Princeton NJ.

Klausen, Jytte, 2004: “Is there an imam problem?", in: Prospect Magazine, Issue 98, May. http://www.prospectmagazine.co.uk/2004/05/isthereanimamproblem/.

Larsson, Göran, 2009: "Imamutbildningar - en europeisk utblick", in: Staten och imamerna: Religion, integration, autonomi, Fritzes, Stockholm: 125-161.

Larsson, Göran, 2010: "Likabehandling eller kontroll? - Om imam- och islamlärarutbildningar”, in: Jenny Berglund, Göran Larsson \& Ulf P. Lundgren (eds.): Att söka kunskap - islamisk utbildning och pedagogic I historia och nutid, Liber, Stockholm.

Nielsen, Jørgen S., 2005: "Who Is Interested in European Imams and Why?", http://www.ku.dk/satsning/religion/indhold/publikationer/anden_litteratur/joerg en_S_Nielsen.pdf.

Schepelern Johansen, Birgitte, 2005: Imamuddannelse $i$ Europa - udfordringer og perspektiver, Satsningsområdet "Religion i det 21. årh.", Københavns Universitet, Copenhagen.

SOU, 2009: Staten och imamerna: Religion, integration, autonomi (The State and the 
imams: religion, integration, autonomy)

Statens offentliga utredningar 2009:52, Fritzes.

http://www.sweden.gov.se/sb/d/11358/a/127317. 